\title{
Erratum: Cancer drugs: remedy required
}

Nat. Med. 17, 231 (2011); published online 7 March 2011; corrected after print 11 March 2011

In the version of this article initially published, the manufacturer of bevacizumab (Avastin) was reported incorrectly as Merck. The manufacturer of bevacizumab is Genentech/Roche. The error has been corrected in the HTML and PDF versions of the article.

The article also states that the US Food and Drug Administration (FDA) approved bevacizumab on the basis of a phase 3 trial that showed a median increase in progression-free survival of 5.9 months, which is consistent with the published literature (N. Engl. J. Med. 357, 2666-2676, 2007). An independent review of the data concluded that the progression-free survival difference was 5.5 months, which is listed on the FDA-approved label for bevacizumab.

On December 15, the FDA's Office of New Drugs (OND) issued a decision memo on Avastin, which states that "it is the conclusion of OND that the breast cancer indication for Avastin be withdrawn." The FDA has granted Genentech/Roche a public hearing on the matter, to be held in June 2011 .

\section{Erratum: Hugging tight in Huntington's}

Ashu Johri, Rajnish K Chaturvedi \& M Flint Beal

Nat. Med. 17, 245-246 (2011); published online 7 March 2011; corrected after print 7 April 2011

In the version of this article initially published, the first author of the primary paper that the N\&V referred to was incorrectly cited as Petrilli. The correct first author is Song. The error has been corrected in the HTML and PDF versions of the article.

\section{Corrigendum: Hugging tight in Huntington's}

\section{Ashu Johri, Rajnish K Chaturvedi \& M Flint Beal \\ Nat. Med. 17, 245-246 (2011); published online 7 March 2011; corrected after print 7 April 2011}

In the version of this article initially published, the authors omitted to mention that L. Scorrano and colleagues had previously shown increased Drp1 activity and mitochondrial fission in cellular models of Huntington's disease and would now like to cite this work (EMBO Mol. Med. 2, 490-503, 2010). The error has been corrected in the HTML and PDF versions of the article.

\section{Corrigendum: Conversion of vascular endothelial cells into multipotent stem-like cells}

\author{
Damian Medici, Eileen M Shore, Vitali Y Lounev, Frederick S Kaplan, Raghu Kalluri \& Bjorn R Olsen \\ Nat. Med. 16, 1400-1406 (2010); published online 21 November 2010; corrected after print 7 April 2011
}

In the version of this article initially published, the flow cytometry plot in Figure $4 \mathrm{~b}$ corresponding to the condition HCMEC and TGF- $\beta 2$ was incorrect. This plot has been replaced with the correct one in the HTML and PDF versions of the article. 